\section{Yellow Squash and Zucchini Cultivar Evaluation in Georgia}

\author{
Timothy Coolong ${ }^{1}$
}

\begin{abstract}
AdDitional Index wORDs. variety trial, Cucurbita pepo, growing degree days, spineless, virus resistance

Summary. Ten yellow squash (Cucurbita pepo) and nine zucchini (C. pepo) cultivars were evaluated in southwest Georgia during spring and fall growing seasons in 2014 and 2015. Plants were grown using plastic mulch and drip irrigation following standard production practices for squash in Georgia. Plants were harvested 10 to 13 times during each study season. Fruit were graded into fancy, medium, and culls. Virus pressure was low during the trials. For yellow squash yields, there were significant cultivar by season interactions; however, Solstice, a straightneck yellow squash, and Gentry, a crookneck cultivar, were consistently among the highest yielding yellow types. Despite having no documented virus resistance, 'Gentry' performed well during the fall season. However, 'Precious II', a yellow straightneck cultivar with the presence of the precocious yellow gene, experienced high cull rates in the fall due to virus effects on the fruit. There was a year by season by cultivar interaction for zucchini yield. Despite this interaction, 'Respect' was ranked among the highest yielding cultivars in all four seasons of the trial. Differences were also observed between seasons for yellow and zucchini squash, with fall yields generally being lower than those in the spring. The results of this study suggest significant differences in the adaptability of squash cultivars for spring and fall production in Georgia. In addition, virus resistance, while important, should not be the exclusive factor for determining cultivars for fall-planted squash in Georgia.
\end{abstract}

S ummer squash is widely grown in spring and fall seasons in southwestern Georgia. Georgia is a significant supplier of yellow (crookneck and straightneck) and zucchini squash for the United States and is typically ranked in the top three nationally in acres planted. In 2014, in Georgia, there were $\approx 8000$ acres of summer squash harvested, valued at over $\$ 52$ million (Wolfe and Stubbs, 2015). About $60 \%$ of the summer squash crop is spring planted, whereas $\approx 35 \%$ is planted in the fall (Guillebeau, 2003). A small percentage of acres are planted during midsummer, as elevated temperatures can reduce yields. Personal observations by the author suggest that about two-thirds of summer squash are grown using plastic mulches. Bareground plantings use overhead irrigation exclusively while those on plastic use drip irrigation.

Disease and insect pressure are lowest in spring plantings, which are started in early to mid-March in southwest Georgia. Growers typically use cultivars with little to no virus resistance in the earliest plantings and

Department of Horticulture, University of Georgia Tifton Campus, 2360 Rainwater Road, Tifton, GA 31793-5766

${ }^{1}$ Corresponding author. E-mail: tcoolong@uga.edu.

doi: 10.21273/HORTTECH03605-16 gradually incorporate those with increased levels of virus resistance as the season progresses. Although cultural methods such as reflective plastic mulches can reduce levels of virus (Boyhan et al., 2000); genetic resistance is the most widely accepted method to reduce the impact of some viruses in squash. The most common viruses observed in Georgia, in squash are potyviruses, often transmitted by cotton aphids [Aphis gossypii (Agrios, 2005)]. Typical potyviruses observed include, Watermelon mosaic virus (WMV), Zucchini yellow mosaic viruses (ZYMV), and Papaya ringspot virus (PRSV) (Mossler and Nesheim, 2004), with the latter two being the most commonly detected in Georgia (B. Dutta, personal communication).
In some years, silverleaf whitefly (Bemisia tabaci) transmitted begomoviruses, such as Cucurbit leaf crumple virus $(\mathrm{CuLCrV})$, can be problematic in Georgia and north Florida (Webb et al., 2013). First identified in the Imperial Valley of California in 1998, infection with $\mathrm{CuLCrV}$ can lead to severe foliar stunting and curling symptoms in zucchini and yellow squash (Hagen et al., 2008). Although stunted, zucchini plants can still produce marketable fruit. However, yellow squash plants will produce fruit with green streaking, rendering them unmarketable (Webb et al., 2013). There are currently no commercial cultivars of squash with documented resistance to $\mathrm{CuLCrV}$.

Transgenic squash cultivars express coat proteins for viruses and are used in some fall plantings due to increased virus pressure. These transgenic cultivars have a high level of resistance to viruses, while conventionally bred types typically contain an intermediate level of resistance or tolerance to virus infection (Tricoli et al., 1995). Results from field trials in Alabama have indicated that when virus pressure is high, transgenic virusresistant yellow squash cultivars can produce yields that are up to fourtimes greater than nonresistant counterparts during the fall production season (Sikora et al., 2008). Due to market resistance to transgenic crops, seed companies continue to introduce traditionally bred cultivars with improved levels of virus resistance. With the judicious use of resistant cultivars, overall losses in Georgia from viruses in squash are usually low (Martinez, 2013). However, in years of high vector pressure, complete losses of plantings without resistance can occur (personal observation).

In addition to incorporating increased disease resistance, seed companies continue to introduce yellow

\begin{tabular}{llll}
\hline $\begin{array}{l}\text { Units } \\
\begin{array}{l}\text { To convert U.S. to SI, } \\
\text { multiply by }\end{array}\end{array}$ & U.S. unit & SI unit & $\begin{array}{l}\text { To convert SI to U.S., } \\
\text { multiply by }\end{array}$ \\
\hline 0.4047 & $\mathrm{acre}(\mathrm{s})$ & $\mathrm{ha}$ & 2.4711 \\
0.3048 & $\mathrm{ft}$ & $\mathrm{m}$ & 3.2808 \\
3.7854 & $\mathrm{gal}$ & $\mathrm{L}$ & 0.2642 \\
2.54 & inch $(\mathrm{es})$ & $\mathrm{cm}$ & 0.3937 \\
0.4536 & $\mathrm{lb}$ & $\mathrm{kg}$ & 2.2046 \\
1.1209 & $\mathrm{lb} / \mathrm{acre}$ & $\mathrm{kg} \cdot \mathrm{ha}^{-1}$ & 0.8922 \\
0.0254 & $\mathrm{mil}$ & $\mathrm{mm}$ & 39.3701 \\
28.3495 & $\mathrm{Oz}$ & $\mathrm{g}$ & 0.0353 \\
1 & $\mathrm{ppm}$ & $\mathrm{mg} \cdot \mathrm{L}^{-1}$ & 1 \\
$\left({ }^{\circ} \mathrm{F}-32\right) \div 1.8$ & ${ }^{\circ} \mathrm{F}$ & ${ }^{\circ} \mathrm{C}$ & $\left({ }^{\circ} \mathrm{C} \times 1.8\right)+32$
\end{tabular}


squash cultivars containing the precocious yellow phenotype. The precocious yellow phenotype is due to the presence of the $\mathrm{B}$-gene and in some cases two or more modifying genes (Shifriss, 1981; Shifriss and Paris, 1981). The presence of the precocious yellow gene(s) may mask the greening symptoms of some viruses, resulting in the production of marketable fruit despite infection.

New cultivars are also continuously being introduced with improved agronomic characteristics. This includes "spineless" zucchini, in which trichomes are largely absent from stems and leaves, facilitating easier harvests and reducing damage to fruit (Xiao and Loy, 2007). Other desired characteristics include compact, bush-type plants, and opencentered growth habits. More compact plants allow for greater plant populations, whereas a more open plant with larger internodes allows for a more efficient harvest.

Despite being a national leader in summer squash production, comprehensive cultivar trials have not been conducted in Georgia for at least two decades. Therefore, in Spring 2014, trials were initiated to evaluate yield and agronomic characteristics in zucchini and yellow squash in southwest Georgia. The objectives of these trials were to identify superior yielding cultivars for spring and fall production seasons.

\section{Materials and methods}

This study was conducted at the University of Georgia, Tifton Vegetable Park in Tifton, GA (lat. $31^{\circ} 5^{\prime} \mathrm{N}$, long. $83^{\circ} 5^{\prime} \mathrm{W}$ ), in 2014 and 2015 . The soil was a Tifton loamy sand series ( $0 \%$ to $2 \%$ slope). Ten and nine cultivars of yellow and zucchini squash, respectively, were planted in all years and seasons (Table 1). Seeds of all cultivars were sown on 14 Mar. and 4 Aug. 2014 and 31 Mar. and 5 Aug. 2015 into 200 -cell trays filled with soilless media (Pro-Mix BX; Premier Tech, Riviere-du-Loup, QC, Canada). Seedlings were greenhouse grown at temperature set points of $84^{\circ} \mathrm{F}$ day/ $68{ }^{\circ} \mathrm{F}$ night for spring plantings and $90^{\circ} \mathrm{F}$ day $/ 68^{\circ} \mathrm{F}$ night) for fall plantings. Plants were watered twice daily as needed and fertilized once daily after germination with a $150 \mathrm{mg} \cdot \mathrm{L}^{-1}$ nitrogen $(\mathrm{N})$ solution $(20 \mathrm{~N}-4.4 \mathrm{P}-16.6 \mathrm{~K}$; Scotts, Marysville, $\mathrm{OH}$ ).
On 28 Mar. and 18 Aug. 2014 as well as 14 Apr. and 14 Aug. 2015, seedlings were planted by hand into raised beds. Plots contained 12 plants with 12-inch in-row spacing for a plant population of 7260 plants/ acre. There were four plots (replicates) of each cultivar and the study was arranged in a randomized complete block design. Plants were grown on 6 -inch-tall by 32 -inch-wide raised beds spaced on 6 - $\mathrm{ft}$ row centers covered with a 1.1-mil-thick totally impermeable film plastic mulch [60 inches wide (Vaporsafe RM; Raven Industries, Sioux Falls, SD)]. Black mulches were used in spring plantings, whereas white-on-black mulches were used in the fall. Soils were fumigated with chloropicrin $(194 \mathrm{lb} / \mathrm{acre})$ and 1,3-dichloropropene (129 lb/acre) (Pic-Chlor 60; TriEst Ag. Group, Tifton, GA) when plastic was laid. Irrigation was supplied with a single line of drip irrigation tubing [ 12 inches emitter spacing, $0.30 \mathrm{gal} / \mathrm{min}$ per $100 \mathrm{ft}$ (Chapin DLX; Jain USA, Haines City, FL)]. About 1 inch of water was applied weekly to plants during growth. Fumigation, plastic laying, and preplant fertilizer were applied using a single raised bed plastic mulch layer with attached fumigation system and fertilizer hopper (SuperBedder; Kennco Manufacturing, Ruskin, FL). Preplant fertility consisted of $50 \mathrm{lb} /$ acre $\mathrm{N}[5.0 \mathrm{~N}-4.3 \mathrm{P}-12.2 \mathrm{~K}$ (Rainbow Plant Food; Agrium, Tifton, GA)] placed in the row immediately before laying plastic mulch. Plants received an additional 96 and $84 \mathrm{lb} /$ acre $\mathrm{N}$ in 2014 and 2015 growing seasons, respectively, through weekly applications $12 \mathrm{lb} /$ acre $\mathrm{N}$ per week liquid fertilizer $[7 \mathrm{~N}-0 \mathrm{P}-5.8 \mathrm{~K}$ (Big Bend Agri-Services, Cairo, GA)] beginning $\approx 10 \mathrm{~d}$ after transplanting.

A row-middle herbicide mixture containing $0.12 \mathrm{lb} /$ acre flumioxazin (Chateau; Valent USA, Walnut Creek, CA), $0.7 \mathrm{lb} /$ acre $S$-metaloachlor (Dual Magnum; Syngenta, Greensboro, $\mathrm{NC}$ ), $0.38 \mathrm{lb} /$ acre ethalfluralin (Curbit 3 EC; Loveland Products, Loveland, $\mathrm{CO}$ ), and $0.84 \mathrm{lb} /$ acre glyphosate (RoundUp WeatherMax; Monsanto, St. Louis, MO) were applied between rows with a shielded sprayer before transplanting. Immediately after planting, the insecticide imidacloprid at $17 \mathrm{lg}$ /acre a.i. (Admire Pro; Bayer Crop Science, Research Triangle Park, NC) was applied through drip irrigation for control squash bug (Anasa tristis). Fungicides and insecticides were applied weekly according to commercial recommendations for summer squash grown in Georgia (Horton, 2016).

Squash were harvested 12 times in 2014, beginning on 5 May and 8 Sept. for spring and fall seasons, respectively. In 2015, squash were harvested 13 and 10 times beginning on 12 May and 8 Sept. in spring and fall, respectively. Spring-planted squash were harvested 37 and $28 \mathrm{~d}$ after planting in 2014 and 2015, respectively; whereas fall-planted squash were harvested 21 and $25 \mathrm{~d}$ after planting in 2014 and 2015, respectively. Squash were harvested every $2 \mathrm{~d}$. All fruit were counted and graded based on a combination of U.S. Department of Agriculture grade standards (USDA, 2016) as well as industry-accepted standards for fancy and medium-grade squash (W. Brim, personal communication) as the USDA grade standards do not dictate specific size requirements. Squash were graded into fancy and medium fruit with average weights of 0.35 and $0.65 \mathrm{lb} /$ fruit, respectively. Fancy fruit were estimated to be $\approx 1$ to 1.5 inches in width and 6 inches in length. Medium fruit were 1.5 to 2 inches in width and up to 8 inches in length. Cull fruit included misshapen or diseased fruit that would not otherwise be marketable. Yields were calculated based on a 22 -lb box that was estimated to contain 60 fancy or 36 medium fruit, respectively. Numbers of fruit per box were based on an average number of fruit counted per box on a commercial packing line (Quality Produce, Ty Ty, GA). Due to the fast growing nature of squash fruit, it was determined that yield should be calculated based on numbers of fruit and not total fruit weight.

In addition to yield, an average spineless rating was determined for zucchini squash. During harvests five through seven, petioles on three plants per plot were examined for the presence of trichomes (spines). Cultivars were scored on a 1-9 scale, with a $\mathrm{l}$ being numerous thick spines and a 9 being virtually spineless. The rating scale took into account both the number and relative thickness of spines. Cultivars with large numbers of small spines that may only feel rough to the touch, but would not 
Table 1. Cultivars, reported resistance, and seed source for yellow squash and zucchini grown at Tifton, GA, in 2014 and 2015.

\begin{tabular}{|c|c|c|c|c|c|}
\hline $\begin{array}{l}\text { Yellow squash } \\
\text { cultivar }\end{array}$ & $\begin{array}{l}\text { Reported } \\
\text { resistance }\end{array}$ & Source ${ }^{\mathrm{z}}$ & $\begin{array}{c}\text { Zucchini squash } \\
\text { cultivar }\end{array}$ & $\begin{array}{l}\text { Reported } \\
\text { resistance }\end{array}$ & Source \\
\hline Cheetah & IR: PRSV, Px, WMV, ZYMV & HM & Esteem & IR: PRSV, Px, WMV, ZYMV & HM \\
\hline Conqueror III & IR: Px, PRSV; HR: CMV, WMV, ZYMV & SE & Justice III & HR: CMV, ZMV, ZYMV & SE \\
\hline Cosmos & IR: PRSV, WMV, ZYMV & $\mathrm{AC}$ & Payload & IR: CMV, Px, WMV, ZYMV & SY \\
\hline Enterprise & - & SY & Respect & IR: PRSV, Px, WMV, ZYMV & HM \\
\hline Gentry $^{\mathrm{x}}$ & - & SY & Spineless Beauty & - & SY \\
\hline Lioness & IR: PRSV, WMV, ZYMV & HM & SV0914YG & IR: Px; HR: CMV, WMV, ZYMV & SE \\
\hline Precious II & $\mathrm{B}$ & $\mathrm{AC}$ & SV6009YG & IR: Px; HR: CMV, WMV, ZYMV & SE \\
\hline Solstice & IR: WMV, ZYMV & $\mathrm{AC}$ & & & \\
\hline
\end{tabular}

$\mathrm{IR}=$ intermediate resistance, $\mathrm{HR}=$ high resistance, $\mathrm{PRSV}=$ Papaya ringspot virus, $\mathrm{Px}=$ powdery mildew caused by Podosphaera xanthii, $\mathrm{WMV}=$ Watemelon mosaic virus, $\mathrm{ZYMC}=$ Zucchini yellow mosaic virus, $\mathrm{CMV}=$ Cucumber mosaic virus, $\mathrm{B}=$ presence of precocious yellow gene(s).

${ }^{\mathrm{z}} \mathrm{AC}=$ Abbott and Cobb (Feasterville, PA), HM = HM Clause (Davis, CA), SE = Seminis Vegetable Seeds (St. Louis, MO), SY = Syngenta Seeds $($ Greensboro, NC0.

'Gentry' and 'Gold Star' were crookneck fruit.

damage fruit, would have been received a higher spineless rating number than cultivars with relatively few but larger spines, which would result in damage to fruit and discomfort for harvesters. Only zucchini were evaluated for spinelessness as several cultivars are currently being marketed as spineless (without trichomes), while there were no spineless yellow cultivars included in this trial.

Weather data were obtained from a nearby on-farm weather station that recorded environmental variables every hour and provided daily maximum, minimum, and total accumulated values [University of Georgia Weather Network, Tifton Station, Tifton, GA (University of Georgia, 2016)]. The following formula was used to estimate growing degree days (GDD); GDD = $\left[\left(\mathrm{T}_{\max }+\mathrm{T}_{\min }\right) / 2\right]-\mathrm{T}_{\text {base }}$. GDD were calculated using a base temperature ( $\mathrm{T}_{\text {base }}$ ) of $45^{\circ} \mathrm{F}$ for squash (Maynard and Hochmuth, 2007) and a daily maximum temperature $\left(\mathrm{T}_{\max }\right)$ of 89.6 ${ }^{\circ} \mathrm{F}$ (NeSmith, 1997). The daily minimum temperature $\left(\mathrm{T}_{\min }\right)$ was used for all calculations except during times when it fell below $\mathrm{T}_{\text {base }}$, then 45 ${ }^{\circ} \mathrm{F}$ was used as $\mathrm{T}_{\text {min }}$.

Data from all cultivars, seasons, and years were analyzed for interactions and main effects using analysis of variance (PROC Mixed), and mean separation using Fisher's least significant difference test $(P<0.05)$ with SAS statistical software (version 9.3; SAS Institute, Cary, NC).

\section{Results and discussion}

Growing CONDITIONs. The Spring 2014 growing season experienced the most rain of any production period in the study, resulting in an increased incidence of bacterial leaf spot (Pseudomonas syringae pv. syringae) on zucchini plants as well as choanephora fruit rot (Choanephora cucurbitarum) in yellow squash fruit (Table 2). The remaining growing seasons received typical rainfall levels for their respective time periods and fungal and bacterial disease pressures were minimal. The accumulated GDD at the first harvest in the spring growing seasons were 737 and 775 in 2014 and 2015, respectively. In Spring 2014, the first harvest occurred $37 \mathrm{~d}$ after transplant (DAT) compared with 28 DAT in Spring 2014. In Spring 2014, seedlings were transplanted $17 \mathrm{~d}$ earlier than in Spring 2015; however, the cool weather experienced in the week after transplanting in Spring 2014 contributed little to GDD accumulation. In Fall 2014 and 2015, the accumulated GDD at first harvest were 766 and 891, respectively. Temperatures for several days after transplanting in Fall 2015 were above $90^{\circ} \mathrm{F}$, resulting in a period of acclimation where plants grew little, despite accumulating more than 150 GDD, resulting in a harvest at a greater GDD in 2015 compared with 2014. Total accumulated GDD for the full harvest season ranged from 1461 in Spring 2014 to 1570 in Spring 2015. When harvests were ended fruit was still being produced, but not at a commercially viable level. Although there is some published information regarding GDD and leaf development in squash (NeSmith 1997; Rouphael et al., 2008), to our knowledge no data have previously been published regarding first harvest of yellow and zucchini squash in response to GDD. This information should prove useful for those planning sequential plantings for spring and fall seasons.

Yellow SQUASH YIELD. There was a significant season by cultivar interaction for yield of yellow squash; however, there was not a significant year by season by cultivar interaction. Therefore data from both study years were merged and yields were evaluated by cultivar and season (Table 3 ). 'Gentry', which produces a crookneck-type fruit, and Solstice, a cultivar that produces a straightneck-type fruit, had significantly greater yields than other cultivars for total and fancy fruit in spring and fall trial seasons. For medium fruit, in the spring trial seasons 'Cosmos' and 'Gold Star' differed significantly with 809 and 563 boxes / acre, respectively, whereas the other cultivars did not differ. Cull rates in the spring study ranged between $6.1 \%$ for 'Solstice' and $10.1 \%$ in 'Gold Prize'. In general, most culls in the spring were due to misshapen fruit often resulting from uneven pollination, as is typical during lower temperatures experienced in the spring. Another reason for culling in spring-grown fruit was from choanephora fruit rot resulting from elevated rainfall.

In the fall-grown yellow squash, 'Gentry' and 'Solstice' had significantly greater yields of total fruit and fancy fruit (Table 3) compared with other cultivars. However, some cultivars such as Precious II and Enterprise had lower relative yields in the fall than in the spring. Conversely, the cultivar Conqueror III had relatively greater yields (higher rank) in the fall than the spring. 'Conqueror III' had 
the highest numerical yield of medium fruit in the fall, though it was not significantly different from six other cultivars. Yields of yellow squash in the fall season of the present study were similar to results for other cultivar trials for fall-grown squash (Rowell et al., 2002; Satanek et al., 2003).

The cull rate of fruit was significantly greater in the fall than in spring (main effects of season not shown). 'Precious II' had a cull rate of $49.9 \%$ in the fall compared with $9.5 \%$ in the spring. Nearly all 'Precious II' fruit were culled due to virus symptoms. Although 'Precious II' contains the gene for precocious yellow (Table 1), which will mask greening associated with Cucumber mosaic virus and WMV, it will not protect fruit from exhibiting greening from ZYMV and PRSV (Shifriss, 1981). Furthermore, while the precocious yellow characteristic will mask greening of fruit, it will not prevent bumps on the surface of fruit caused by the infecting virus. Nearly, all fruit from 'Precious II' were culled due to a bumpy appearance and not greening. It is notable that earlier trials conducted in Kentucky noted that 'Precious II' had a relatively poor appearance, though not specifically due to virus symptoms (Satanek et al., 2003).

Interestingly, yields of 'Gentry' were not significantly different from 'Solstice', the highest yielding cultivar in the fall. 'Gentry' has no documented virus resistance and does not contain the precocious yellow gene. Therefore, it was expected that cull rates due to virus in 'Gentry' would have been high in the fall. While symptoms of ZYMV were present on some 'Gentry' plants and confirmed by The University of Georgia Plant Pathology Diagnostic Laboratory, overall cull rates (12.8\%) and losses to virus were lower than some cultivars. Similarly, Rowell et al. (2002) noted that yields of 'Gentry' grown in the fall were no different from

Table 2. The maximum $\left(T_{\max }\right)$ and minimum $\left(T_{\min }\right)$ temperatures, accumulated growing degree days (GDD) to first and last harvest as well as accumulated rainfall during the study period for squash grown at Tifton, GA, in 2014 and 2015.

\begin{tabular}{|c|c|c|c|c|c|}
\hline & $\underline{T}_{\max }$ & $T_{\min }$ & GDD First & GDD Final & Rainfall \\
\hline & & & harvest $^{\mathbf{y}}$ & harvest & (inches) $^{\mathrm{z}}$ \\
\hline 2014 & & & & & \\
\hline Spring & 91.7 & 37.5 & 737 & 1,461 & 16.5 \\
\hline Fall & 97.5 & 44.3 & 766 & 1,554 & 7.3 \\
\hline 2015 & & & & & \\
\hline Spring & 90.2 & 49.7 & 775 & 1,570 & 4.9 \\
\hline Fall & 95.2 & 54.5 & 891 & 1,527 & 3.3 \\
\hline
\end{tabular}

${ }^{2}\left({ }^{\circ} \mathrm{F}-32\right) \div 1.8={ }^{\circ} \mathrm{C}, \mathrm{l}$ inch $=2.54 \mathrm{~cm}$.

${ }^{\mathrm{y}} \mathrm{GDD}=\left[\left(\mathrm{T}_{\max }+\mathrm{T}_{\min }\right) / 2\right]-45^{\circ} \mathrm{F} ; \mathrm{T}_{\max }$ limited to $89.6^{\circ} \mathrm{F}$.

Table 3. Marketable yields for total, fancy, and medium fruit harvested as well as cull rates for yellow squash grown at Tifton, GA, in 2014 and 2015.

\begin{tabular}{|c|c|c|c|c|c|c|c|c|}
\hline \multirow[b]{3}{*}{ Cultivar } & \multicolumn{4}{|c|}{ Spring } & \multicolumn{4}{|c|}{ Fall } \\
\hline & \multicolumn{3}{|c|}{$(\text { boxes/acre) })^{\mathrm{z}}$} & \multirow{2}{*}{$\begin{array}{l}(\%)^{\mathrm{y}} \\
\text { Cull } \\
\end{array}$} & \multicolumn{3}{|c|}{ (boxes/acre) } & \multirow{2}{*}{$\begin{array}{c}(\%) \\
\text { Cull } \\
\end{array}$} \\
\hline & Total & Fancy $^{x}$ & $\operatorname{Medium}^{\mathbf{x}}$ & & Total & Fancy & Medium & \\
\hline Solstice & $2,360 \mathrm{a}$ & $1,620 \mathrm{a}$ & $740 \mathrm{ab}$ & $6.1 \mathrm{~b}$ & $1,730 \mathrm{a}$ & $1,320 \mathrm{a}$ & $410 \mathrm{ab}$ & $12.4 \mathrm{~d}$ \\
\hline Cosmos & $2,050 \mathrm{~b}$ & $1,240 \mathrm{bc}$ & $810 \mathrm{a}$ & $9.2 \mathrm{ab}$ & $1,410 \mathrm{bc}$ & $1,090 \mathrm{~b}$ & $320 \mathrm{abc}$ & $22.2 \mathrm{~b}$ \\
\hline Precious II & $1,920 \mathrm{bc}$ & $1,280 \mathrm{~b}$ & $640 a b$ & $9.5 \mathrm{ab}$ & $770 \mathrm{f}$ & $560 \mathrm{e}$ & $210 \mathrm{c}$ & $49.9 \mathrm{a}$ \\
\hline Lioness & $1,850 \mathrm{bc}$ & $1,110 \mathrm{bcd}$ & $740 \mathrm{ab}$ & $8.3 \mathrm{ab}$ & 1,220 cde & $890 \mathrm{c}$ & $330 \mathrm{ab}$ & $20.4 \mathrm{~b}$ \\
\hline Conqueror III & $1,750 \mathrm{c}$ & $1,100 \mathrm{~cd}$ & $650 \mathrm{ab}$ & $9.9 \mathrm{a}$ & $1,490 \mathrm{~b}$ & $1,070 \mathrm{~b}$ & $420 \mathrm{a}$ & $14.2 \mathrm{~cd}$ \\
\hline Cheetah & $1,720 \mathrm{c}$ & $1,040 \mathrm{~d}$ & $680 \mathrm{ab}$ & $7.4 \mathrm{ab}$ & $1,070 \mathrm{e}$ & $670 \mathrm{de}$ & $400 \mathrm{ab}$ & $20.0 \mathrm{~b}$ \\
\hline Gold Star & $1,690 \mathrm{c}$ & $1,130 \mathrm{bcd}$ & $560 \mathrm{~b}$ & $8.1 \mathrm{ab}$ & 1,220 cde & $930 \mathrm{bc}$ & $290 \mathrm{bc}$ & $11.6 \mathrm{~d}$ \\
\hline
\end{tabular}

${ }^{\mathrm{z}}$ One $22-\mathrm{lb}(10.0 \mathrm{~kg})$ box contained 60 fancy or 36 medium fruit, respectively; l box $/$ acre $=24.6587 \mathrm{~kg} \cdot \mathrm{ha}^{-1}$.

${ }^{\mathrm{y}}$ Cull percentage is based on nonmarketable fruit due to shape, color, or presence of virus divided by total number of fruit harvested

${ }^{\mathrm{x}}$ Fancy fruit $=1$ to 1.5 -inch diameter and 6 -inch length, medium fruit $=1.5$ to 2 -inch diameter and $\leq 8$-inch length; 1 inch $=2.54 \mathrm{~cm}$

"Values in the same column and year followed by the same letter are not significantly different at $P \leq 0.05$ according to Fisher's least significant difference test. 
Table 4. Marketable yields for total, fancy, and medium fruit harvested as well as cull rates for zucchini squash grown at Tifton, GA, in 2014 and 2015.

2014

\begin{tabular}{|c|c|c|c|c|c|c|c|c|}
\hline \multirow{2}{*}{ Cultivar } & \multicolumn{4}{|c|}{ Spring } & \multicolumn{4}{|c|}{ Fall } \\
\hline & \multicolumn{3}{|c|}{ (boxes/acre) $^{\mathrm{z}}$} & $\begin{array}{l}(\%)^{\mathrm{y}} \\
\text { Cull } \\
\end{array}$ & \multicolumn{3}{|c|}{ (boxes/acre) } & $\begin{array}{c}\%) \\
\text { Cull }\end{array}$ \\
\hline SV6009YG & $1,450 \mathrm{a}^{\mathrm{w}}$ & $720 \mathrm{a}$ & $740 \mathrm{a}$ & $8.3 \mathrm{ab}$ & $1,030 \mathrm{ab}$ & $600 \mathrm{~b}$ & $430 \mathrm{ab}$ & $15.0 \mathrm{de}$ \\
\hline Respect & $1,210 \mathrm{ab}$ & $670 a$ & $540 \mathrm{ab}$ & $12.7 \mathrm{a}$ & $1,190 \mathrm{a}$ & $710 a$ & $480 \mathrm{a}$ & $12.9 \mathrm{e}$ \\
\hline SV0914YG & $1,180 \mathrm{~b}$ & $660 a$ & $520 \mathrm{~b}$ & $8.6 \mathrm{ab}$ & $810 \mathrm{c}$ & $480 \mathrm{c}$ & $330 \mathrm{bc}$ & $19.0 \mathrm{de}$ \\
\hline SV0474YG & $1,170 \mathrm{~b}$ & $700 \mathrm{a}$ & $470 \mathrm{~b}$ & $6.2 \mathrm{bc}$ & $1,020 \mathrm{~b}$ & $600 \mathrm{~b}$ & $420 \mathrm{ab}$ & $18.3 \mathrm{de}$ \\
\hline Payload & \multicolumn{4}{|c|}{$\mathrm{NA}^{\mathrm{v}}$} & $1,000 \mathrm{~b}$ & $630 \mathrm{ab}$ & $370 \mathrm{abc}$ & $18.1 \mathrm{de}$ \\
\hline Spineless King & \multicolumn{4}{|c|}{$\mathrm{NA}$} & $660 \mathrm{~cd}$ & $290 \mathrm{e}$ & $370 \mathrm{abc}$ & $35.6 \mathrm{a}$ \\
\hline Spineless Beauty & \multicolumn{4}{|c|}{ NA } & $590 \mathrm{~d}$ & 320 de & $270 \mathrm{c}$ & $28.0 \mathrm{bc}$ \\
\hline
\end{tabular}

2015

\begin{tabular}{|c|c|c|c|c|c|c|c|c|}
\hline \multirow{2}{*}{ Cultivar } & \multicolumn{4}{|c|}{ Spring } & \multicolumn{4}{|c|}{ Fall } \\
\hline & \multicolumn{3}{|c|}{ (boxes/acre) } & $\begin{array}{c}(\%) \\
\text { Cull } \\
\end{array}$ & \multicolumn{3}{|c|}{ (boxes/acre) } & $\begin{array}{c}\%) \\
\text { Cull }\end{array}$ \\
\hline Respect & $1,840 \mathrm{a}$ & $1,100 \mathrm{a}$ & $740 \mathrm{a}$ & $12.0 \mathrm{bcd}$ & $1,210 \mathrm{a}$ & $840 \mathrm{a}$ & $380 \mathrm{ab}$ & $8.1 \mathrm{bc}$ \\
\hline SV6009YG & $1,620 \mathrm{bc}$ & $980 \mathrm{ab}$ & $650 \mathrm{ab}$ & $9.5 \mathrm{~d}$ & $980 \mathrm{bc}$ & $730 \mathrm{ab}$ & $250 \mathrm{bcd}$ & $12.1 \mathrm{bc}$ \\
\hline SV0914YG & $1,600 \mathrm{bc}$ & $900 \mathrm{bc}$ & $700 \mathrm{a}$ & $8.9 \mathrm{~d}$ & $710 \mathrm{~d}$ & $510 \mathrm{~cd}$ & $200 \mathrm{~d}$ & $9.8 \mathrm{bc}$ \\
\hline Justice III & $1,450 \mathrm{~cd}$ & 770 cde & $680 \mathrm{ab}$ & $17.7 \mathrm{a}$ & $1,090 \mathrm{ab}$ & $640 \mathrm{bc}$ & $440 \mathrm{a}$ & $17.0 \mathrm{ab}$ \\
\hline Esteem & $1,400 \mathrm{~d}$ & $730 \mathrm{de}$ & $660 \mathrm{ab}$ & $11.0 \mathrm{~cd}$ & $650 \mathrm{~d}$ & $420 \mathrm{~d}$ & $230 \mathrm{~cd}$ & $9.3 \mathrm{bc}$ \\
\hline Spineless King & $1,130 \mathrm{e}$ & $620 \mathrm{e}$ & $510 \mathrm{~b}$ & $16.5 \mathrm{ab}$ & $640 \mathrm{~d}$ & $390 \mathrm{~d}$ & $250 \mathrm{bcd}$ & $23.0 \mathrm{a}$ \\
\hline
\end{tabular}

${ }^{\mathrm{z}}$ One $22-\mathrm{lb}(10.0 \mathrm{~kg})$ box contained 60 fancy or 36 medium fruit, respectively; 1 box $/ \mathrm{acre}=24.6587 \mathrm{~kg} \cdot \mathrm{ha}^{-1}$

${ }^{y}$ Cull percentage is based on nonmarketable fruit due to shape, color, or presence of virus divided by total number of fruit harvested.

${ }^{\mathrm{x}}$ Fancy fruit $=1$ to 1.5 -inch diameter and 6 -inch length, medium fruit $=1.5$ to 2 -inch diameter and $\leq 8$-inch length; 1 inch $=2.54 \mathrm{~cm}$.

"Values in the same column and year followed by the same letter are not significantly different at $P \leq 0.05$ according to Fisher's least significant difference test.

${ }^{\mathrm{N} A}=$ not available for analysis in Spring 2014 due to an outbreak of bacterial leaf spot resulting in large stand losses of those cultivars.

(Schultheis and Walters, 1998; Sikora et al., 2008). With the exception of 'Precious II' and to a lesser extent 'Enterprise', the decrease in yield in the fall compared with spring was not closely associated with virus infection. In fact, overall incidences of virus in both years in the fall were low for the region and limited to one or two plants per plot, with the exceptions of 'Precious II' and 'Enterprise'. No virus was observed in any plants in the spring. This suggests that a cultivar such as Conqueror III may be better adapted for fall production than other cultivars, regardless of the level of virus resistance. This may be expected as 'Conqueror III' was selected primarily for fall production.

ZuCChINI SQUASH YIELD. There was a significant year by season by cultivar interaction for total yield of zucchini squash (Table 4 ). In three of the four seasons, 'Respect', a mediumgreen fruited cultivar, had the numerically greatest total yield. In Spring 2014, 'SV6009YG', a dark-green fruited cultivar, was numerically the highest yielding cultivar. Nonetheless, 'Respect' was not significantly different from 'SV6009YG' for any yield category in Spring 2014. In Spring 2014, three cultivars, Payload, Spineless King, and Spineless Beauty were unable to be harvested due to an outbreak of bacterial leaf spot on transplants resulting from cool wet conditions at planting (Table 2 ). In 2015 , total yields in fall were $\approx 50 \%$ or less than spring total yields for 'Esteem', 'Spineless King', 'Spineless Beauty', and 'SV0914YG'. The only zucchini cultivar that experienced large decreases in fall productivity that had no virus resistance was Spineless Beauty. Although a sample taken from 'Spineless Beauty' plots was confirmed positive for ZYMV, few (one to two per plot) plants exhibited any symptoms. The other cultivars experiencing large decreases in fall yields had no observable virus symptoms, suggesting that the primary reason for reduced yields was not virus related, but linked to other environmental conditions. Furthermore, while cull rates increased for 'Spineless Beauty' and 'Spineless King' to $23.3 \%$ and $23.0 \%$, respectively; the culls were due to poorly shaped fruit that curved more than market tolerances, but were clearly not the result of virus infection. An earlier trial conducted by Rowell et al. (2002) noted that 'Spineless Beauty' fruit was tapered and larger on the blossom end. Conversely, 'Justice III' is a transgenic cultivar with high levels of virus resistance that it ranked relatively higher among the cultivars for yield in Fall 2015, compared with spring. However, in 2014, 'Justice III' had lower yields than several cultivars in the fall season. Cull rates of 'Justice III' were high $(34.3 \%)$ in Fall 2014, resulting from fruit that tended to be bulbous at the blossom end. This suggests that virus resistance is important, but not necessarily the only consideration for fall production of zucchini squash and that, 
Table 5. Spine ratings for zucchini squash grown in Tifton, GA, in 2014 and 2015.

\begin{tabular}{lcccc}
\hline & \multicolumn{2}{c}{$\mathbf{2 0 1 4}$} & \multicolumn{2}{c}{$\mathbf{2 0 1 5}$} \\
\cline { 2 - 5 } Cultivar & \multicolumn{3}{c}{ Spines (1-9 scale) } \\
\cline { 2 - 5 } Spring & Fall & Spring & Fall \\
SV0914 & $7.5 \mathrm{a}^{\mathrm{y}}$ & $8.0 \mathrm{~b}$ & $7.5 \mathrm{~b}$ & $8.8 \mathrm{a}$ \\
Ev6009 & $7.0 \mathrm{ab}$ & $7.0 \mathrm{~cd}$ & $6.5 \mathrm{c}$ & $7.2 \mathrm{bc}$ \\
Respect & $6.3 \mathrm{bc}$ & $7.5 \mathrm{bc}$ & $6.3 \mathrm{c}$ & $7.7 \mathrm{~b}$ \\
Justice III & $6.3 \mathrm{bc}$ & $6.5 \mathrm{~d}$ & $6.0 \mathrm{c}$ & $6.7 \mathrm{c}$ \\
SV0474 & $5.8 \mathrm{c}$ & $7.0 \mathrm{~cd}$ & $5.8 \mathrm{c}$ & $7.0 \mathrm{bc}$ \\
Spineless King & $5.8 \mathrm{c}$ & $5.3 \mathrm{~d}$ & $5.8 \mathrm{c}$ & $7.7 \mathrm{~b}$ \\
Spineless Beauty & $\mathrm{NA}$ & $9.0 \mathrm{a}$ & $9.0 \mathrm{a}$ & $8.8 \mathrm{a}$ \\
Payload & $\mathrm{NA}$ & $9.0 \mathrm{a}$ & $8.8 \mathrm{a}$ & $8.8 \mathrm{a}$ \\
SAy & $\mathrm{NA}$ & $7.8 \mathrm{bc}$ & $6.1 \mathrm{c}$ & $6.3 \mathrm{c}$ \\
\hline
\end{tabular}

${ }^{\mathrm{z}}$ Spineless ratings done on a 1 to 9 scale where $1=$ large and numerous spines, $9=$ virtually spineless.

'Values in the same column and year followed by the same letter are not significantly different at $P \leq 0.05$ according to Fisher's least significant difference test.

${ }^{x} \mathrm{NA}=$ not available for analysis in Spring 2014 due to an outbreak of bacterial leaf spot resulting in large stand losses of those cultivars.

despite high levels of virus resistance; some cultivars are not well suited to production under fall growing conditions.

Because of a significant cultivar by season by year interaction, main effects are not presented. However, as with yellow squash, total yield averages for zucchini squash in fall were significantly lower than in spring in 2014 and 2015 (data not shown). For both years, the average total yield of zucchini decreased $35.5 \%$ in the fall compared with spring. There were 13 harvests in Spring 2015 and 10 in Fall 2015 , which may account for a portion of the decrease in yield in fall. However, it was unlikely that additional harvests in Fall 2015, would have increased yields significantly as the plants were producing few if any fruit when harvests were ended. Furthermore, in 2014, there were an equal number of harvests in spring and fall there were significant decreases in yield for all cultivars in the fall.

ZUCCHINI SQUASH SPINELESSNESS. A spineless rating was taken on the petioles of zucchini plants during all four trial seasons because several zucchini cultivars are marketed based on having spineless attributes. There was a cultivar by season by year interaction for spineless ratings (Table 5). As expected, the two cultivars that are sold as "spineless" types, Spineless King and Spineless Beauty, were virtually spineless and had the highest spineless rating in Fall 2014 and Spring 2015. A new cultivar, SV0914, a medium-green fruited zucchini, had the highest spineless rating in Spring 2014 (when both Spineless King and
Spineless Beauty were removed from the trial) and was grouped with the two spineless-cultivars in Fall 2015. With the exception of 'SV0474' in 2014, zucchini plants had higher spineless values in fall compared with spring. Relative differences in the spineless ratings among cultivars in the different seasons and years resulted in the threeway interaction. In both study years, 'Esteem' and 'Justice III' had the largest increase in spineless ratings between spring and fall, while changes in 'Respect' were lower. Although the presence of trichomes (spines) is genetically dependent (Xiao and Loy, 2007), the environment may impact the expression of spines on zucchini plants. For most cultivars trialed, results suggest that growing conditions in the fall in southwest Georgia lessen the levels of spines present.

\section{Conclusion}

Several published cultivar trials of summer squash have focused on the impact of virus resistance on yield (Rowell et al., 2002; Satanek et al., 2003; Schultheis and Walters, 1998; Sikora et al., 2008). However, while yields were related to level of virus resistance in some of those studies (Sikora et al., 2008); virus pressure was sufficiently low in others such that resistance levels were not well correlated with yield (Rowell et al., 2002; Satanek et al., 2003). In the present trial, cotton aphid populations were typical for the fall; however, virus pressure was fairly low. The low levels of virus pressure in the four study seasons allowed for an evaluation of yield potential affected primarily by different growing conditions present in spring and fall. If virus pressure in the fall were high, as is typical for southwest Georgia, then the results of this study could have been quite different. Under typical levels of virus pressure, those cultivars with high levels of virus resistance would have likely exhibited significantly higher yields than those with low or even intermediate levels of resistance.

Because of the low virus levels in the fall plantings, the relative performance of the cultivars as affected by the different weather conditions typical to spring and fall plantings were able to be evaluated. Temperatures at which fruit are produced during the most productive harvest periods (harvests three to eight) were higher in the fall than in spring. These higher temperatures may have affected pollination or fruit development/shape, which could have resulted in significantly higher cull rates in the fall, despite low virus levels. Several yellow squash cultivars had fruit culled due to having a "ribbed" appearance, whereas zucchini cultivars were culled due to having a curvature or a bulbous shape at the tip.

The straightneck cultivar, Solstice, had high yield potential in spring and fall as well as intermediate resistance to WMV and ZYMV. Although 'Gentry', a crookneck cultivar, exhibited a high-yield potential in spring and fall seasons in this study, the lack of virus resistance would limit usage of this cultivar in regions with high virus pressure. The high cull rates associated with 'Precious II', also suggested that the presence of the precocious yellow gene(s) may not be adequate for reducing losses due to virus.

Although there were significant year by season by cultivar interactions for productivity of zucchini squash, Respect, was numerically the highest yielding cultivar in three of the four seasons trialed and was always statistically grouped with highest yielding cultivars. This suggests that 'Respect' is widely adaptable to production over a range of climate conditions. In addition, due to the low virus incidence in this study, we can conclude that lower yields encountered in the fall seasons were likely the result of the climate conditions routinely 
encountered in the fall. In addition to cultivar recommendations, this information will be useful for estimating crop yields and crop-loss estimates for fall-grown yellow squash and zucchini in the southeastern United States. Lower yields typically encountered in the fall may at times be erroneously attributed to losses due to disease.

\section{Literature cited}

Agrios, G.N. 2005. Plant pathology. 5th ed. Elsevier, Burlington, MA.

Boyhan, G.E., J.E. Brown, C. ChannelButcher, and V.K. Perdue. 2000. Evaluation of virus resistant squash and interaction with reflective and nonreflective mulches. HortTechnology 10:574-580.

Guillebeau, P. 2003. Crop profile for squash in Georgia. 6 Sept. 2016. <https://ipmdata.ipmcenters.org/ documents/cropprofiles/GAsquash. pdf $>$.

Hagen, C., M.R. Rojas, T. Kon, and R.L. Gilbertson. 2008. Recovery from cucurbit leaf crumple virus (family Geminiviridae, genus Begomovirus) infection is an adaptive antiviral response associated with changes in viral small RNAs. Phytopathology 98:1029-1037.

Horton, D. 2016. 2016 Georgia pest management handbook. Vol. 1. Univ. Georgia Coop. Ext. Serv. Bul. SB-28-1.

Martinez, A.E. 2013. 2013 Georgia plant disease loss estimates. Univ. Georgia Coop. Ext. Serv. Bul. AP-102-6.
Maynard, D.N. and G.J. Hochmuth. 2007. Knott's handbook for vegetable growers. 5th ed. Wiley, Hoboken, NJ.

Mossler, M.A. and O.N. Nesheim. 2004. Florida crop/pest management profile: Squash. Univ. Florida IFAS Ext. Serv. Circ. CIR-1265.

NeSmith, S.D. 1997. Summer squash (Cucurbita pepo L.) leaf number as influenced by thermal time. Sci. Hort. 68:219-225.

Rouphael, Y., M. Carderelli, C. Fallovo, G. Colla, A. Salerno, E. Rea, and A. Marucci. 2008. Predicting leaf number of greenhouse zucchini squash using degree days and photosynthetically active radiation. Acta Hort. 801:1149-1154.

Rowell, B., W. Nesmith, A. Satanek, and D. Slone. 2002. Yield and powdery mildew resistance of fall-harvested summer squash. Fruit Veg. Res. Rpt. Univ. Kentucky Coop. Ext. Serv. Bul. PR-470.

Satanek, A., B. Rowell, W. Nesmith, D. Slone, and J.C. Snyder. 2003. Yield and powdery mildew resistance of fallharvested summer squash. Fruit Veg. Res. Rpt. Univ. Kentucky Coop. Ext. Serv. Bul. PR-488.

Schultheis, J.R. and S.A. Walters. 1998. Yield and virus resistance of summer squash cultivars and breeding lines in North Carolina. HortTechnology 8:3139.

Shifriss, O. 1981. Origin, expression, and significance of gene $B$ in Cucurbita pepo L. J. Amer. Soc. Hort. Sci. 106:220-232.

Shifriss, O. and H.S. Paris. 1981. Identification of modifier genes affecting the extent of precocious fruit pigmentation in
Cucurbita pepo L. J. Amer. Soc. Hort. Sci. 106:653-660.

Sikora, E.J., J.F. Murphy, and J. Burkett. 2008. Performance of virus resistant transgenic yellow summer squash in Alabama. J. Veg. Sci. 12:75-83.

Tricoli, D.M., K.J. Carney, P.F. Russell, J. R. McMaster, D.W. Groff, K.C. Hadden, P.T. Himmel, J.P. Hubbard, M.L. Boeshore, and H.D. Quemada. 1995. Field evaluation of transgenic squash containing single or multiple virus coat protein gene constructs for resistance to cucumber mosaic virus. Biotechnology 13:1458-1465.

University of Georgia. 2016. Tifton, Georgia climate data. 9 Sept. 2016. <http://www.georgiaweather.net/ index . php ? conten $\mathrm{t}=\mathrm{c}$ alculat or $\&$ variable $=C C \&$ site $=$ TIFTON $>$.

U.S. Department of Agriculture. 2016. United States standards for grades summer squash. U.S. Dept. Agr., Washington, DC.

Webb, S.E., F. Akad, T.W. Nyoike, E. Liburd, and J.E. Polston. 2013. Whiteflytransmitted cucurbit leaf crumple virus in Florida. Univ. Florida IFAS Ext. Serv. Fact Sheet. ENY-477.

Wolfe, K. and K. Stubbs. 2015. 2014 Georgia farm gate value report. Univ. Georgia Coop. Ext. Serv. Bul. AR-15-01.

Xiao, Q. and J.B. Loy. 2007. Inheritance and characterization of a glabrous trait in summer squash. J. Amer. Soc. Hort. Sci. 132:327-333. 